\title{
Effect of the pressure of the carrier gas and the crystal size on the growth forms of ice crystals grown from the vapor
}

\author{
Junichi NAMBA* and Takehiko GondA**
}

\begin{abstract}
Single ice crystals were formed on a rabbit hair in helium gas of 1 and 10 atm at $-14^{\circ} \mathrm{C}$ and a supersaturation of $12 \%$. Long needles grow with high frequency in the gas of $10 \mathrm{~atm}$, which never grow in the gas of $1 \mathrm{~atm}$.

Next, ice crystals were formed in helium gas of $10 \mathrm{~atm}$ at $-14^{\circ} \mathrm{C}$ and at high and low supersaturations, and their growth forms were studied. The size ratio $\mathrm{c} / \mathrm{a}$ of ice crystals formed at a low supersaturation hardly depends on crystal size, while that at a high supersaturation depends markedly on crystal size and its dependence is mainly determined by the size ratio c/a of minute ice crystals of about $30 \mu \mathrm{m}$.
\end{abstract}

\section{Introduction}

Earlier studies on the growth forms of snow crystals have been made by Nakaya (1951, 1954) and others, and they have been summarized as “Nakaya's diagram". Then, Kobayashi's diagram $(1957,1961)$ has been offered as a revised edition of it.

According to the Kobayashi's diagram, the habit of snow crystals depends on air temperature, and the morphological instability of them depends on the degree of supersaturation. However, the growth forms of snow crystals depend not only on the factors described above but also on others, for example, air pressure, crystal size and surface structure of the crystals.

Looking over the earlier studies, we can see the difference among experimental results of Isono et al. (1957) and Isono (1958), those of Kobayashi (1958) and Van den Heuvel et al. (1959), which depends on the difference in the size of ice crystals formed between them. After that, the effects

\footnotetext{
* Atugi Minami High School, Atugi, Kanagawa 243, Japan.

(Present address: Ebina High School, Ebina, Kanagawa 243-04, Japan)

** Faculty of Science and Technology, Science University of Tokyo, Noda, Chiba 278, Japan.
}

of the kind and pressure of carrier gas on the growth forms of small ice crystals have been investigated in detail (Isono and Iwai, 1969, 1971; Komabayasi, 1970; Gonda and Komabayasi, 1970, 1971; Gonda, 1976, 1977, 1980).

Thereafter, the effects of the pressure of carrier gas on the growth forms of ice crystals above and below $200-300 \mu \mathrm{m}$ in size have been studied (Gonda and Namba, 1981), as a result, it has been found that the habit of ice crystals below 200$300 \mu \mathrm{m}$ in size is remarkably affected by the pressure of carrier gas, but that above $200-300 \mu \mathrm{m}$ in size is hardly affected.

Recently, a theory to explain the temperature dependence of snow crystal habit has been proposed by Kuroda and Lacmann (1982) and Kuroda (1982).

The first purpose of this paper is to study quantitatively the effect of the pressure of carrier gas and the crystal size on the growth forms of ice crystals growing in helium gas of 1 and $10 \mathrm{~atm}$ at $-14^{\circ} \mathrm{C}$ and a supersaturation of $12 \%$.

The second is to study the effects of the supersaturation and crystal size on the growth forms of ice crystals growing in high pressure helium gas at $-14^{\circ} \mathrm{C}$. 


\section{Experimental procedures}

The experimental apparatus is shown in detail in a previous paper (Gonda and Namba, 1981). A growth chamber is made of a cylinder of $7.3 \mathrm{~cm}$ in inner diameter and immersed in the ethylene glycol-water mixture cooled down to about $-20^{\circ} \mathrm{C}$. An ice plate made from $25 \mathrm{~cm}^{3}$ distilled water, which is set on the bottom of the growth chamber was used as a water vapor source by flowing an electric current to a $\mathrm{SnO}_{2}$ coating glass placed at the bottom of the ice plate. Ice crystals were grown on a rabbit hair which was stretched horizontally at the place of $1.2 \mathrm{~cm}$ above the ice plate, and we observed growing ice crystals in situ using a differential interference microscope through an observation window set at the top of the chamber. The air in the chamber was pumped out using a vacuum pump, after that, helium gas was introduced into the chamber until the pressure of helium gas became slightly higher than a desired pressure.

After the rabbit hair was fully dried, the supersaturation in the chamber was increased to nucleate an ice crystal on the rabbit hair. A small amount of helium gas was allowed to escape out of the chamber to induce slightly additional cooling of a crystallization site due to an adiabatic expantion. In the case that many ice crystals were nucleated on the rabbit hair, almost all of them were sublimated by flowing an electric current to the $\mathrm{SnO}_{2}$ film coated on the observation window, and only a few ice crystals were left in the microscope field of view.

After ice nucleation, the temperature of the crystallization site (rabbit hair) was kept at $-14^{\circ} \mathrm{C}$ and the pressure of helium gas was kept at 1 or $10 \mathrm{~atm}$. The degree of supersaturation was determined from the temperature difference between the rabbit hair and the upper surface of the ice plate. The supersaturation was kept at a constant value by keeping the surface temperature of the ice plate at $0.2^{\circ} \mathrm{C}$ during the experiments of ice crystal growth.

\section{Experimental results}

3.1 Dependence on pressure of carrier gas and crystal size of the growth forms of ice crystals grown at $-14^{\circ} \mathrm{C}$ and a supersaturation of $12 \%$

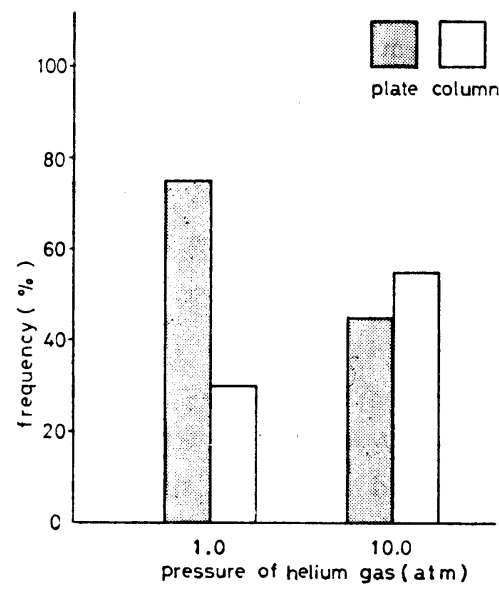

(a)

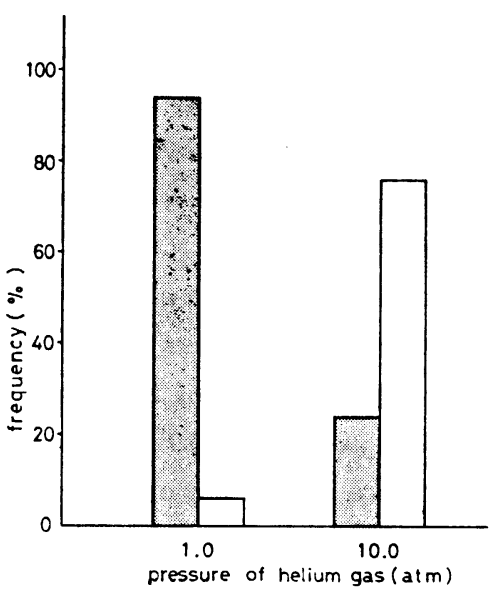

(b)

Fig. 1 The growth frequency of plate-like and column-like ice crystals grown in helium gas of 1 and $10 \mathrm{~atm}$ at $-144^{\circ} \mathrm{C}$ and a supersaturation of $12 \%$.

(a) ice crystals of about $50 \mu \mathrm{m}$

(b) ice crystals above $100 \mu \mathrm{m}$ 
Figure 1 shows the growth frequency of platelike and column-like ice crystals of about 100 crystals grown in helium gas of 1 and $10 \mathrm{~atm}$ at $-14^{\circ} \mathrm{C}$ and a supersaturation of $12 \%$. In helium gas of $1 \mathrm{~atm}$, the growth frequency of plate-like ice crystals is about $75 \%$ of all ice crystals when the crystal size is about $50 \mu \mathrm{m}$, while it becomes to about $94 \%$ when the crystal size grows about $100 \mu \mathrm{m}$. In helium gas of $10 \mathrm{~atm}$, the growth frequency of columnar ice crystals is about $55 \%$ when the crystal size is about $50 \mu \mathrm{m}$, while it becomes to about $76 \%$ when the crystal size grows about $100 \mu \mathrm{m}$.

These facts mean that the habit of ice crystals remarkably depends on the pressure of carrier gas and on the crystal size.

Figure 2 shows the relationship between the size ratio $c / a$ of ice crystals and the size of ice crystals grown in helium gas of 1 (a) and 10 (b)

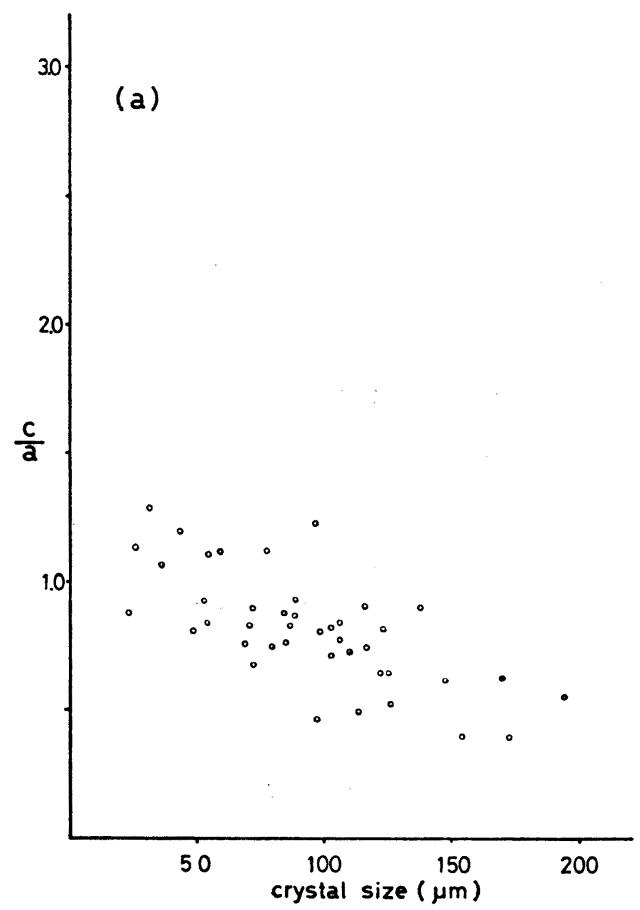

atm at $-14^{\circ} \mathrm{C}$ and a supersaturation of $12 \%$. Here, the size ratio c/a shows the ratio of the length along c-axis of ice crystals and that of aaxis.

When the gas pressure is $1 \mathrm{~atm}$, the size ratio c/a of ice crystals decreases with increasing crystal size. That is, when the crystal size grows above about $100 \mu \mathrm{m}$, ice crystals become plate-like even when the size ratio $c / a$ of ice crystals in early stage of growth is about 1.0.

On the other hand, when the gas pressure is $10 \mathrm{~atm}$, obtained results can be roughly classified as follows. The first case is that the value of $c / a$ of ice crystals increases with increasing crystal size, as a natural consequence, ice crystals become long needles (e.g. Fig. 3). The second case is that the value $\mathrm{c} / \mathrm{a}$ of ice crystals decreases with increasing crystal size, as a result, ice crystals become thin dendrites (e.g. Fig. 4).

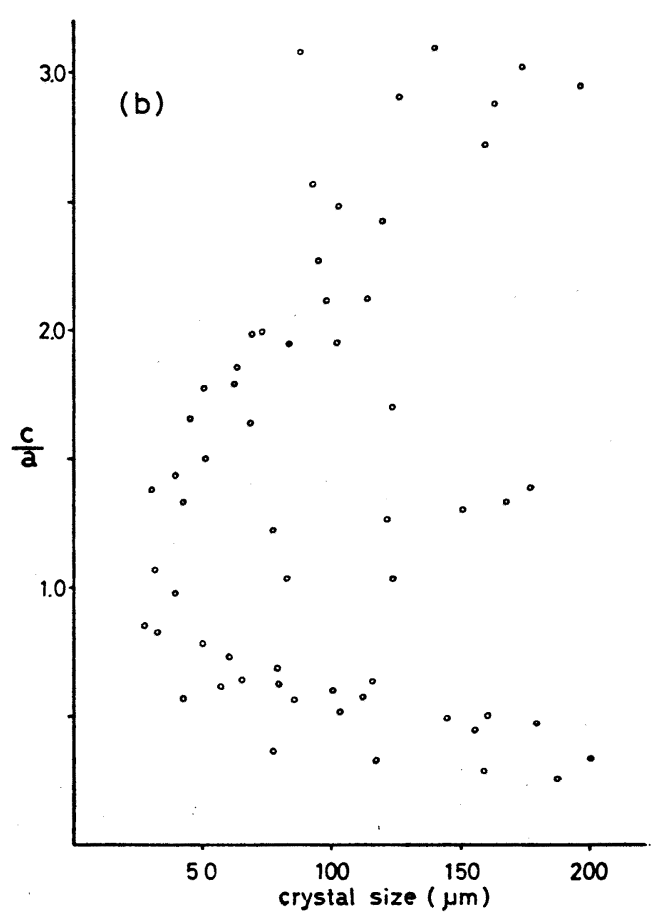

Fig. 2 The relationship between the size ratio $c / a$ of ice crystals and the size of ice crystals and the size of ice crystals grown in helium gas of 1 and 10 atm at $-14^{\circ} \mathrm{C}$ and a supersaturation of $12 \%$.

(a) in helium gas of $1 \mathrm{~atm}$

(b) in helium gas of $10 \mathrm{~atm}$ 

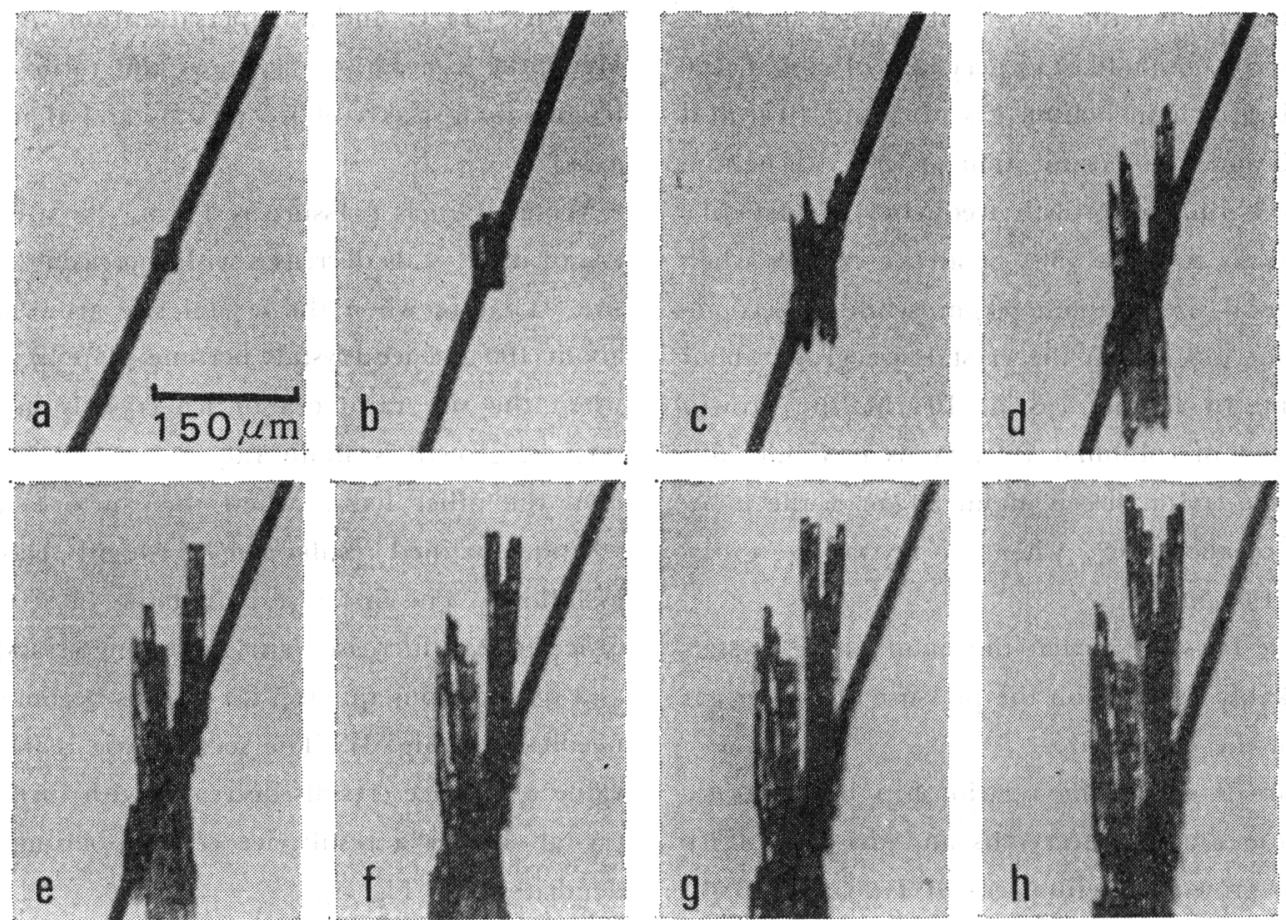

Fig. 3 Long needle grown in helium gas of $10 \mathrm{~atm}$ at $-14^{\circ} \mathrm{C}$ and a supersaturation of $12 \%$.

(a) 2, (b) $5, \quad$ (c) 7, (d) 9, (e) 11, (f) 13, (g) 15, (h) $17 \mathrm{~min}$.
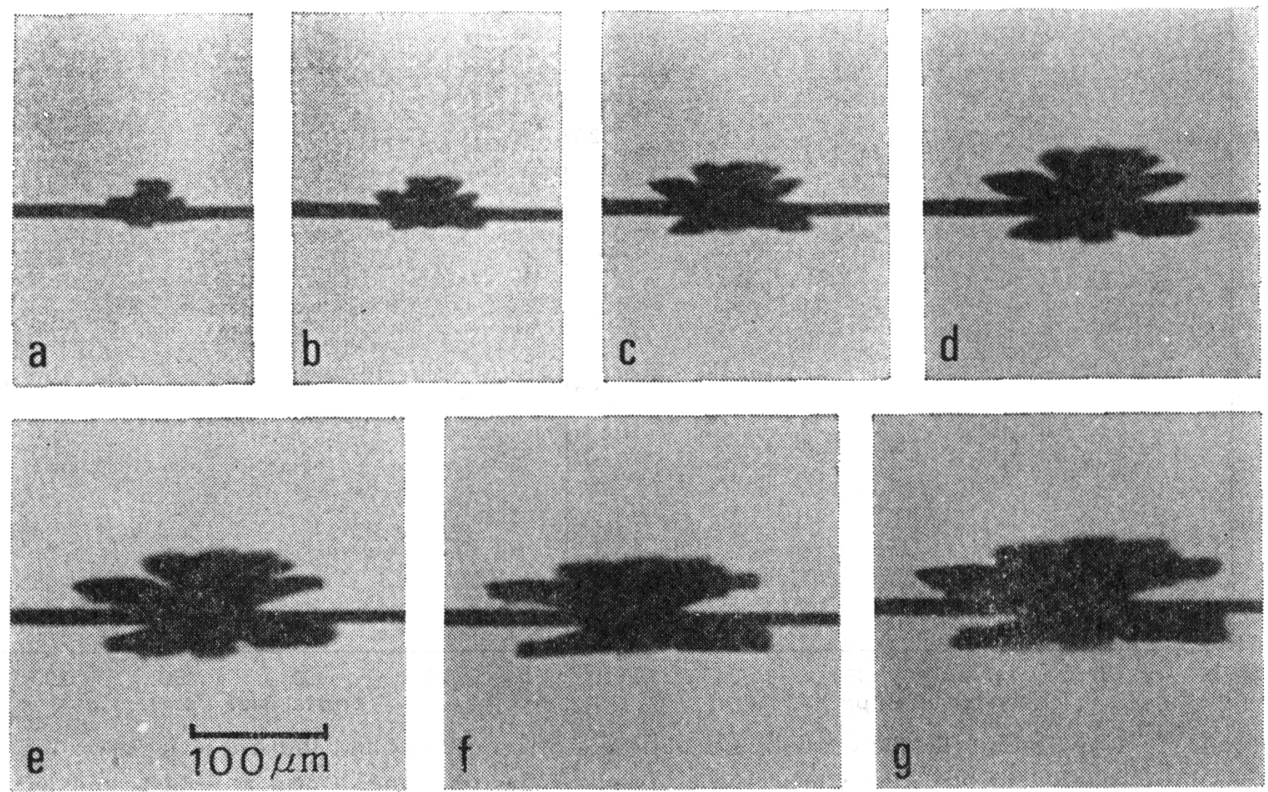

Fig. 4 Thin dendrite grown in helium gas of $10 \mathrm{~atm}$ at $-14^{\circ} \mathrm{C}$ and a supersaturation of $12 \%$.
(a) 2 ,
(b) 7, (c) 12 ,
(d) 17,
(e) 22 , (f) 27 ,
(g) $32 \mathrm{~min}$. 
Consequently, in helium gas of $10 \mathrm{~atm}$, long needles which are never formed in helium gas of $1 \mathrm{~atm}$ are formed. Moreover thinner dendrites than those formed in helium gas of $1 \mathrm{~atm}$ are formed although their frequency is small (about $24 \%$ ).

3.2 Dependence on supersaturation and crystal size of the growth forms of ice crystals grown in the gas of $10 \mathrm{~atm}$ at $-14^{\circ} \mathrm{C}$

In the case of ice crystals growing in helium gas of $10 \mathrm{~atm}$ at $-14^{\circ} \mathrm{C}$ and a supersaturation of $2 \%$, polyhedral plate-like and column-like crystals are simultaneously formed when the crystal size is below about $30 \mu \mathrm{m}$. After that, the skeletal structures are formed on the $(0001)$ or $(10 \overline{1} 0)$ faces with increasing crystal size. Figure 5 shows the size ratio $\mathrm{c} / \mathrm{a}$ of ice crystals grown in helium gas of $10 \mathrm{~atm}$ at $-14^{\circ} \mathrm{C}$ and a supersaturation of $2 \%$ versus the crystal size. Generally speaking, the size ratio $\mathrm{c} / \mathrm{a}$ of the crystal with skeletal struc-

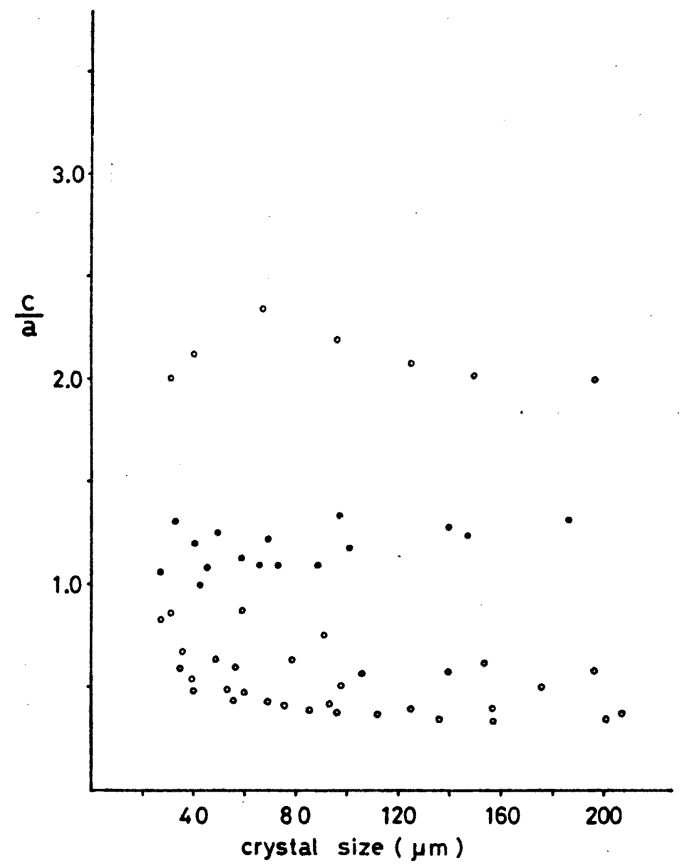

Fig. 5 Crystal size dependence of the size ratio c/a of ice crystals grown in helium gas of $10 \mathrm{~atm}$ at $-14^{\circ} \mathrm{C}$ and a supersaturation of $2 \%$ : tures on the $(10 \overline{1} 0)$ face tends to decrease with increasing crystal size when the crystal is relatively small. On the other hand, the size ratio $c / a$ of the crystals with the skeletal structures on the (0001) face tends to increase with increasing crystal size when the crystals are relatively small. However, as shown in the figure, it is understood that the size ratio $c / a$ of ice crystals formed at a supersaturation of $2 \%$ hardly depends on crystal size.

On the other hand, in the case of ice crystals grown in helium gas of $10 \mathrm{~atm}$ at $-14^{\circ} \mathrm{C}$ and a supersaturation of $12 \%$, the skeletal structures are formed on both the (0001) and (1010) faces of larger ice crystals than about $20 \mu \mathrm{m}$ in size. After that, the protuberances are formed in the [0001] or $[11 \overline{2} 0]$ directions at each corner of the crystals

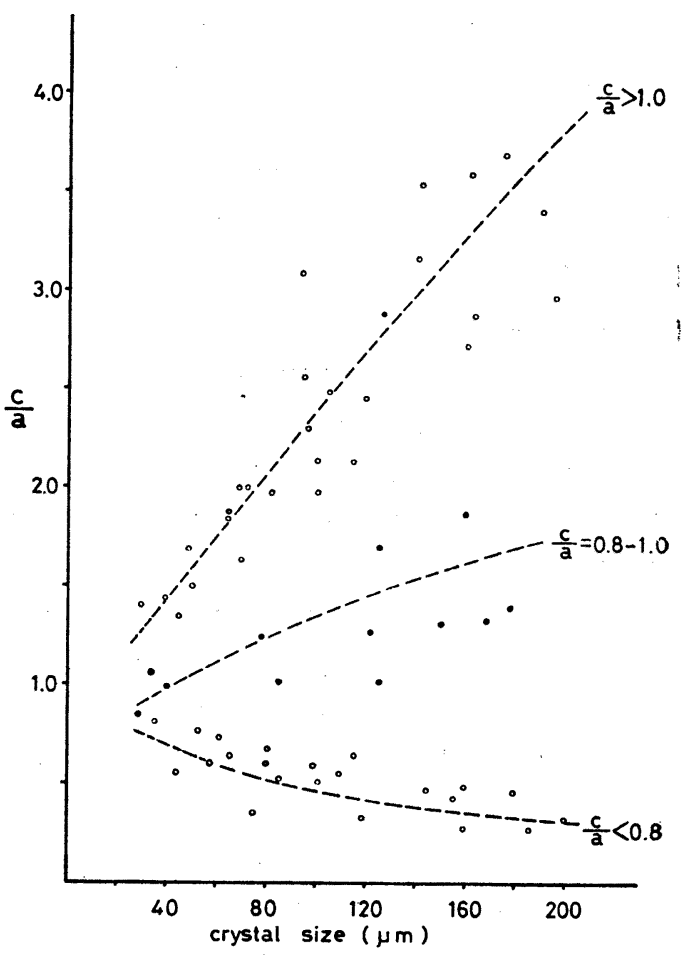

Fig. 6 Crystal size dependence of the size ratio c/a of ice crystals grown in helium gas of $10 \mathrm{~atm}$ at $-14^{\circ} \mathrm{C}$ and a supersaturation of $12 \%$. The size ratios $\mathrm{c} / \mathrm{a}$ in the figure are those of ice crystals of about $30 \mu \mathrm{m}$ in size. 
with increasing crystal size. Figure 6 shows the crystal size dependence of the size ratio $\mathrm{c} / \mathrm{a}$ of ice crystals grown in helium gas of $10 \mathrm{~atm}$ at $-14^{\circ} \mathrm{C}$ and a supersaturation of $12 \%$. In the figure, the values of the size ratio $\mathrm{c} / \mathrm{a}$ are those of ice crystals of about $30 \mu \mathrm{m}$. In the case of minute ice crystals with size ratio larger than 1.0 , the size ratios $\mathrm{c} / \mathrm{a}$ of the crystals increase with increasing crystal size because the protuberances are formed in the [0001] directions at the corners of the crystals, as a result, very narrow needles are formed with increasing crystal size.

In the case of minute ice crystals with the size ratio of 0.8-1.0, columnar ice crystals with size ratio smaller than 2.0 are formed with increasing crystal size.

In the case of minute ice crystals with size ratio smaller than 0.8 , the size ratio $\mathrm{c} / \mathrm{a}$ of the crystals decrease with increasing crystal size because the protuberances are formed in the [11 20$]$ directions at the corners of the crystals, as a result, very thin dendrites are formed with increasing crystal size. However, the frequency which dendrites are formed is about $24 \%$.

\section{Discussion}

Ice crystals formed in helium gas of $10 \mathrm{~atm}$ at $-14^{\circ} \mathrm{C}$ and a supersaturation of $2 \%$ are polyhedral when the crystal size is below about $30 \mu \mathrm{m}$. This tendency coincides with previous results obtained by Gonda et al. (1982, 1983, 1985). By the way, under the growth conditions described above, skeletal structures are formed with increasing crystal size, and ice crystals with skeletal structures on the (0001) face have a tendency to grow as colunmar ice crystals, while ice crystals with skeletal structures on the (10ī0) face have a tendency to grow as plate-like ice crystals. This result means that the surface instability of ice crystals is one of the important factors which control the growth forms of ice crystals.

Next, the reason why the size ratio $\mathrm{c} / \mathrm{a}$ of ice crystals grown at a supersaturation of $2 \%$ hardly depends on the crystal size is that at such low supersaturation, the surface kinetic process of water molecules is more important than the volume diffusion process of water molecules onto the crystal surfaces as the rate-determining process.

On the other hand, in the case of ice crystals grown in helium gas of $10 \mathrm{~atm}$ at $-14^{\circ} \mathrm{C}$ and a supersaturation of $12 \%$, the skeletal structures are formed even when the crystal size is about $20 \mu \mathrm{m}$. This fact means that the size which ice crystals growing in high pressure gas at high supersaturation become unstable is about $20 \mu \mathrm{m}$.

As shown in Fig. 4, in early growth stage, minute ice crystals with size ratio smaller than 0.8 grow as very thin dendrites with increasing crystal size. Similarly, minute ice crystals with the size ratio of $0.8-1.0$ grow as columnar ice crystals with the size ratio smaller than 2.0 with increasing crystal size. Moreover, minute ice crystals with the size ratio larger than 1.0 grow as very long needles. These experimental results mean that the size ratio of ice crystals growing in high pressure gas at high supersaturation is mainly determined by the volume diffusion process of water molecules toward the crystals. That is to say, the growth forms of ice crystals growing in high pressure gas at high supersaturation is determined by the size ratio $\mathbf{c} / \mathbf{a}$ of minute ice crystals of about $30 \mu \mathrm{m}$.

\section{Conclusions}

The growth forms of ice crystals grown in helium gas of 1 and $10 \mathrm{~atm}$ at $-14^{\circ} \mathrm{C}$ were studied by varying the degree of supersaturation. Obtained results are as follows.

(1) In the case of ice crystals grown above $100 \mu \mathrm{m}$ in size in helium gas of $1 \mathrm{~atm}$, the formation frequency of plate-like ice crystals is about $94 \%$, while in helium gas of $10 \mathrm{~atm}$ that of columnar ice crystals is about $76 \%$.

(2) Most of the columnar ice crystals formed in helium gas of $10 \mathrm{~atm}$ are long needles, and most of plate-like ice crystals whose formation 
frequency is small (about 24\%) are thin dendrites.

(3) The size ratio $\mathrm{c} / \mathrm{a}$ of ice crystals growing in high pressure gas at $-14^{\circ} \mathrm{C}$ and at low supersaturation hardly depends on crystal size.

(4) The size ratio $\mathrm{c} / \mathrm{a}$ of ice crystals growing in high pressure gas at $-14^{\circ} \mathrm{C}$ and at high supersaturation depends markedly on crystal size and their growth forms are determined by the size ratio $c / a$ of minute ice crystals of about $30 \mu \mathrm{m}$.

(5) The crystal size dependence of the size ratio of ice crystals growing in high pressure gas at high supersaturation is concerned with the formation of skeletal structures and protuberances on the (0001) or (10ī0) faces of the crystals.

(6) The growth forms of ice crystals grown in high pressure gas at low supersaturation depend on the surface kinetic process of water molecules toward the crystals, while those at high supersaturation depend on the volume diffusion process of water molecules onto the crystal surface.

\section{References}

Gonda, T., 1976: The growth of small ice crystals in gases of high and low pressures. J. Meteor. Soc. Japan, 54, 233-240.

Gonda, T., 1977: The growth of small ice crystals in gases of high and low pressures at -30 and $-44^{\circ} \mathrm{C}$. J. Meteor. Soc. Japan, 55, 142-146.

Gonda, T., 1980: The influence of the diffusion of vapor and heat on the morphology of ice crystals grown from the vapor. J. Cryst. Growth, 49, 173181.

Gonda, T. and Gomi, H., 1985: Morphological instability of polyhedral ice crystals growing in air at a low temperature. Annals of Glaciology, 6 (in press).

Gonda, T. and Koike, T., 1983: Growth mechanisms of single ice crystals growing at a low temperature and their morphological stability. J. Cryst. Growth, 64, 36-42.
Gonda, T. and Komabayasi, M., 1970: Growth of ice crystals in the atmospheres of helium-argon mixture. J. Meteor. Soc. Japan, 48, 440-451.

Gonda, T. and Komabayasi, M., 1971: Skeletal and dendritic structures of ice crystals as a function of thermal conductivity and vapor diffusivity. $\mathrm{J}$. Meteor. Soc. Japan, 49, 32-42.

Gonda, T. and Namba, J., 1981: Effect of the diffusion field of water vapor and the crystal size on the morphology of ice crystals grown from the vapor phase. J. Cryst. Growth, 52, 60-63.

Gonda, T. and Yamazaki, T., 1982: Morphological stability of polyhedral ice crystals grown from the vapor phase. J. Cryst. Growth, 60, 259-263.

Isono, K., 1958: Mode of growth of ice crystals in air and other gases. Nature, 182, 1221-1222.

Isono, K. and Iwai, K., 1969: Growth mode of ice crystals in air at low pressure. Nature, 223, 11491150.

Isono, K. and Iwai, K., 1971: Growth rate and habit of ice crystals in air at low pressure. J. Meteor. Soc. Japan, Special Issue, 49, 836-844.

Isono, K. Komabayasi, M. and Ono, A., 1957: On the habit of ice crystals grown in the atmosphere of hydrogen and carbon dioxide. J. Meteor. Soc. Japan, 35, 17-28.

Kobayashi, T., 1957: Experimental researches on the snow-crystal habit and growth by means of a diffusion cloud chamber. J. Meteorol. Soc. Japan, 75th Anniv. Vol., 38-47.

Kobayashi, T., 1958: On the habit of snow crystals artificially produced at low pressure. J. Meteor. Soc. Japan, 36, 193-208.

Kobayashi, T., 1961: The growth of snow crystals at low supersaturation. Phil. Mag., 6, 1363-1370.

Komabayasi, M., 1970: Shape instability of crystals of ice, carbon dioxide and ammonia grown in cold chamber. J. Meteor. Soc. Japan, 48, 270-286.

Kuroda, T., 1982: Growth kinetics of ice single crystal from the vapour phase and variation of its growth forms. J. Meteorol. Soc. Japan, 60, 520-534.

Kuroda, T. and Lacman, R., 1982: Growth kinetics of ice from vapour phase and its growth forms. J. Cryst. Growth, 56, 189-205.

Nakaya, U., 1951: The formation of ice crystals. Com- 
pendium Meteor., (Amer. Meteor. Soc. Boston), Van den Heuvel A. P. and Mason, B. J., 1959: Habit 207-220.

of ice crystals grown in hydrogen, carbon dioxide

Nakaya, U., 1954: Snow crystals, Natural and artificial, and air at reduced pressure. Nature, 184, 519-520.

Harvard Univ. Press., Cambridge.

要 旨

$-14^{\circ} \mathrm{C}$, 過飽和度一定 $(12 \%)$ 下でヘリウムガスの庄力を変えて (10気圧, 1 気圧), 兔毛上に氷 晶を成長させたところ，10気圧の気体中では，1気圧の下では成長しない長い針状結晶が高い頻度 で成長した。 また， $-14^{\circ} \mathrm{C} ， 10$ 気圧のへリウムガス中で過飽和度を変えて，水晶を成長させ，その 成長形を研究したところ，低過飽和度で成長する氷晶のサイズ比 $\mathrm{c} / \mathrm{a}$ は, 結晶サイズにほとんど估 存しないが, 高過飽和度で成長する氷晶のサイズ比 $\mathrm{c} / \mathrm{a} は ，$ 結晶サイズに大きく依存し，それらは， 約 $30 \mu \mathrm{m}$ の微細水晶のサイズ比 $\mathrm{c} / \mathrm{a}$ で決まることがわかった。

(Received 26 June 1985; revised manuscript accepted 24 October 1985) 